\title{
Peran Kualitas Komite Audit dalam Hubungan Corporate Social Responsibility dengan Kualitas Laba
}

\author{
An-Nisha Dewi Puspaningrum*, MG Kentris Indarti \\ Fakultas Ekonomika dan Bisnis, Universitas Stikubank (UNISBANK) Semarang \\ Jl. Kendeng V Bendan Ngisor, Semarang, Indonesia \\ *Correspondence e-mail: annishadewip@gmail.com, kentris@edu.unisbank.ac.id
}

\begin{abstract}
Abstrak. Penelitian ini bermaksud untuk menguji dan menganalisis pengaruh Corporate Social Responsibility (CSR) terhadap kualitas laba dengan kualitas komite audit sebagai variabel moderasi. Populasi dalam penelitian ini merupakan perusahaan manufaktur yang telah terdaftar di Bursa Efek Indonesia (BEI) dari tahun 2017-2019. Metode pengambilan sampel menggunakan metode purposive sampling dan menghasilkan 243 data akhir. Hasil penelitian menjelaskan bahwa CSR berpengaruh positif terhadap kualitas laba. Sebaliknya, kualitas komite audit tidak berpengaruh terhadap kualitas laba dan hasil moderasi kualitas komite audit memperlemah pengaruh CSR terhadap kualitas laba. Hasil penelitian ini dapat disimpulkan bahwa CSR begitu penting di dalam perusahaan yang terkait oleh perilaku opportunistik yang dilakukan seorang manajer karena ada kaitannya dengan keberlanjutan perusahaan. Namun demikian, kualitas komite audit belum berpengaruh secara optimal terhadap peningkatan kualitas laba karena masih belum berperan penting, karena kualitas komite audit masih sebatas berperan sebagai pemenuhan syarat dari Otoritas Jasa Keuangan (OJK) di dalam suatu perusahaan yang telah terdaftar di Bursa Efek Indonesia (BEI).
\end{abstract}

Kata kunci: Corporate Social Responsibility; Kualitas Komite Audit; Kualitas Laba

\begin{abstract}
This study intends to examine and analyze the effect of Corporate Social Responsibility (CSR) on earnings quality with audit committee quality as a moderating variable. The population in this study is a manufacturing company that has been listed on the Indonesia Stock Exchange (IDX) from 2017-2019. The sampling method used purposive sampling method and produced 243 final data. The results of the study explain that CSR has a positive effect on earnings quality. In contrast, the quality of the audit committee has no effect on earnings quality and the moderating results of the quality of the audit committee weaken the effect of CSR on earnings quality. The results of this study can be concluded that CSR is very important in the company which is related to the opportunistic behavior of a manager because it is related to the sustainability of the company. However, the quality of the audit committee has not optimally affected the increase in earnings quality because it has not played an important role, because the quality of the audit committee is still limited to its role as a fulfillment of the requirements of the Financial Services Authority (OJK) in a company that has been listed on the Indonesia Stock Exchange (IDX).
\end{abstract}

Keywords: Corporate Social Responsibility; Audit Committee Quality; Earnings Quality

\section{PENDAHULUAN}

Pada laporan keuangan, pengambilan ketetapan ekonomi digunakan sebagai target tujuannya ialah pengambilan ketetapan ekonomi khususnya bagi perusahaan yang ingin memanfaatkannya karena di dalam laporan keuangan menggambarkan informasi penting kepada publik. Laporan keuangan memiliki bagian salah satunya ialah laporan laba rugi yang mampu menyediakan laba (earnings) pada suatu periode yang dicapai perusahaan. Untuk melihat kualitas laba pada perusahaan, investor membutuhkan informasi laba karena dapat menurunkan risiko informasi

Informasi laba sangat penting untuk para pengguna karena hal ini membuat perusahaan akan semakin menaikkan kualitas labanya. Akan tetapi, terdapat beberapa kelompok atau golongan tertentu yang melaksanakan kebiasaan tidak baik untuk menggapai misi individunya. Dengan demikian, sering terjadi praktik manipulasi laba yang dilakukan oleh manajemen perusahaan yang sudah mengerti situasi dalam perusahaan.
Hal itu bertujuan agar investor bersedia untuk menginvestasikan dana pada perusahaannya. Peristiwa ini mengakibatkan laba perusahaan menjadi tidak berkualitas. Apabila laba berkualitas, investor akan membagikan sinyal positif melalui kesanggupannya menanamkan sahamnya yang tentunya akan memajukan kelangsungan hidup suatu perusahaan (Aryengki et al, 2016).

Laba didefinisi sebagai ciptaan akuntansi akrual yang berfungsi menjadi sarana ukur kualitas laba administrasi perusahaan. Kualitas laba sendiri merupakan kinerja laba untuk menjelaskan suatu informasi yang di dalamnya memiliki fungsi guna mendukung pengambilan keputusan (Witjaksono dan Djaddang, 2018). Apabila kualitas laba dijelaskan secara teratur maka laba tersebut akan semakin berkualitas. Kualitas laba merupakan usaha untuk melindungi kapabilitas perusahaan di awal dan akhir waktu agar selalu sama terpaut jumlah yang digunakan saat satu periode. Kualitas laba sebagai ukuran yang dapat menyesuaikan laba yang diperoleh dengan apa yang 
sebelumnya direncanakan apakah sudah sama (Bawoni dan Shodiq, 2020). Menurut Hutasoit, Harahap \& Huda (2020), perusahaan yang menyampaikan kualitas laba dengan baik dan jelas akan mengungkapan labanya secara transparan maka informasi laba yang diperoleh merupakan keadaan yang sebenarnya bukan rekayasa.

Pada umumnya, perusahaan didirikan dengan maksud untuk mendatangkan laba. Tetapi, sekarang ini para pemangku kepentingan mengupayakan agar perusahaan tidak hanya semata-mata mendapatkan laba tetapi juga melaksanakan tanggung jawab sosial perusahaan atau Corporate Social Responbility (CSR). Semua aspek kegiatan usaha yang dilaksanakan perusahaan terkait dengan isu CSR yang saat ini justru bertambah meningkat dan menjadi informasi yang di butuhkan bagi pelanggan, investor beserta stakeholder yang memerlukan transparasi. Ada banyak manfaat yang diperoleh perusahaan yang melaksanakan CSR seperti biaya modal menjadi lebih rendah, reputasi dan kinerja keuangan semakin baik serta menarik lebih banyak investor. CSR berkontribusi di suatu perusahaan yang diharapkan dapat membangun citra positif untuk meningkatkan kualitas laba bagi pemangku kepentingan (Rahmawardani dan Muslichah, 2020)

Menurut Hutasoit, Harahap \& Huda (2020), praktik CSR di negara Indonesia telah memperoleh perhatian cukup besar. Peristiwa ini di latarbelakangi karena berbagai fenomena yang terjadi seperti contohnya produsen mobil jepang yang masih digemparkan kasus manipulasi data dan penurunan produksi penjualan yang dilakukan mantan CEO Carlos Ghosn, kemudian kasus yang terjadi pada tanggal 24 April 2019 yang sampai menarik perhatian publik karena terjadi pemalsuan pada laporan keuangan tahun buku 2018 lalu pada PT. Garuda Indonesia. Selanjutnya kasus ketiga yang diduga memanipulasi data kartu kredit dan diperkirakan dengan jumlah sebanyak 100.000 kartu lebih yang telah dimodifikasi, kasus tersebut terjadi pada PT. Bank Bukopin Tbk (BBKP). Perubahan tersebut mengakibatkan status kredit dan pendapatan berbasis komisi Bukopin semakin meningkat tidak sewajarnya. Contoh dari peristiwa diatas, dapat di simpulkan bahwa perusahaan dalam menyampaikan laporan keuangannya tidak memberikan informasi labanya secara benar dan transparan. Sebagai pedoman pengambilan keputusan, hal ini tidak dapat memprediksi kinerja keuangan perusahaan yang nyata karena rekayasa tersebut tidak relevan dan tidak yakin untuk digunakan (Bawoni dan Shodiq, 2020). Pada kasus diatas, terdapat penyimpangan fungsi laporan keuangan, hal tersebut menimbulkan laporan keuangan yang sepatutnya menjadi pedoman ketika memilih keputusan justru mampu mengelirukan dan merugikan para investor. Dengan munculnya implementasi CSR, manajemen berupaya meningkatkan nama baik suatu perusahaan dan menyampaikan pendapat yang positif terhadap stakeholder. Karena apabila stakeholder dengan perusahaan mempunyai hubungan yang baik maka akan memperoleh efek jangka panjang implementasi CSR.

Corporate Social Responbility (CSR) merupakan suatu sikap perusahaan yang bertanggung jawab kepada masyarakat atau lingkungan sekitar. Agar dapat menjalankan ekspetasi dari berbagai pemangku kepentingan dan melaksanakan adanya kontrak sosial, perusahaan berusaha untuk menerapkan CSR. Tercantum pada Undang-Undang No. 40 Tahun 2007 perihal Perseroan Terbatas, yakni mengatur tentang kewajiban perusahaan untuk menyelenggrakan tanggung jawab sosial perusahaan. Pemerintah Indonesia juga ikut serta mendukung penerapan dan pengungkapan CSR bagi suatu perusahaan (Lestari dan Feliana, 2019). CSR termasuk strategi bisnis perusahaan dalam menaikkan kualitas laba pada laporan tahunan perusahaan. Kualitas laba merupakan sudut pandang utama dari kualitas pelaporan keuangan. Alasan manajemen melaksanakan pelaporan sosial adalah agar CSR dapat dijadikan benteng untuk manajemen memanipulasi pendapatan (manajemen laba). Karena manajemen yang tinggi akan menyebabkan kualitas laba menjadi lebih rendah sedangkan manajemen yang rendah akan menciptakan kualitas laba yang tinggi (Hutasoit, Harahap \& Huda, 2020).

Stakeholder theory menjadi dasar untuk melakukan penelitian tentang tanggung jawab sosial perusahaan atau CSR dengan kualitas laba. Stakeholder theory membuktikan bahwa suatu perusahaan mempunyai dorongan untuk melaksanakan tanggung jawab sosial perusahaan dengan maksud mengimplementasikan kontrak sosial, melengkapi ekspetasi pemangku kepentingan, dan untuk berperilaku etis. Perusahaan yang menjalankan tanggung jawab sosial perusahaannya dapat melaporkan laporan keuangannya secara transparan, mempunyai kualitas akrual tinggi, dan tingkat manajemen yang rendah. Hal ini berdasarkan hasil penelitian yang dilakukan di beberapa negara Asia, Amerika Serikat dan Eropa. Hasil penelitian ini, menguatkan stakeholder theory dan dapat memperkuat kedudukan suatu perusahaan bahwa suatu perusahaan berperilaku etis dengan melaksanakan tanggung jawab sosial (Kristiawan, 2020).

Adanya suatu permasalahan kepentingan, keberadaan kualitas komite audit berfungsi sebagai jaminan transparansi atas laporan keuangan, keadilan bagi stakeholder, dan semua pengungkapann informasi yang dilaksanakan manajemen (Sayuthi, 2017). Forum for Corporate Governance in Indonesian (FCGI) memberi pendapat bahwa kualitas komite audit mempunyai maksud untuk menolong dewan komisaris demi melengkapi tanggung jawab dalam menyerahkan pemeriksaan secara komperehensif atas berlangsungnya aktivitas perusahaan. Semakin tinggi kualitas yang dimiliki komite audit, maka menunjukkan semakin baik pula karakteristik yang ada pada dewan komisaris. 
Sebagian peneliti telah melakukan penelitian sebelumnya antara lain menurut Hutasoit, Harahap \& Huda (2020) serta Lestari dan Feliana (2019) yang menyatakan bahwa CSR tidak memiliki pengaruh signifikan terhadap kualitas laba. Hasil penelitian tersebut membuktikan, begitu pentingnya peran kualitas komite audit untuk menilai perusahaan karena termasuk salah satu penyebab yang mempengaruhi penilaian publik, investor serta kreditur agar mendapatkan informasi laba yang berkualitas. Investor merupakan kelompok luar perusahaan yang tidak boleh mengawasi, mengecek, memeriksa bahkan mengetahui secara langsung mengenai praktik informasi kualitas laba. Dengan demikian, kualitas laba dapat dilihat sebagai pembandingan perusahaan terhadap keyakinan investor dengan kinerja kualitas komite sebagai pengaruhnya.

Berdasarkan penjelasan tersebut, maka penelitian ini ingin menguji kembali peran kualitas komite audit sebagai variabel moderasi antara pengaruh CSR dengan kualitas laba.

\section{Pengaruh Corporate Social Responbility (CSR) Terhadap Kualitas Laba}

Tanggung jawab sosial perusahaan terikat dengan teori stakeholder. Teori stakeholder menjelaskan apabila perusahaan hendak meneruskan operasional usahanya, maka perusahaan harus melaksanakan ekspetasi masyarakat. Melalui pelaporan kualitas laba yang buruk pengungkapan CSR seringkali dianggap untuk menutupi perilaku buruk perusahaan. Suatu perusahaan terikat dalam perilaku oportunistik yang telah dilakukan manajer dengan kualitas laba sebagai cerminan (Hutasoit, Harahap \& Huda, 2020).

Menurut Aziz dan Faisol (2018), Hoang et al (2018), Rezae et al., (2019), Kristiawan (2020), dan Hidayah et al., (2021), menyampaikan bahwa CSR ada pengaruh positif dengan kualitas laba perusahaan.

H1: CSR berpengaruh positif terhadap kualitas laba

\section{Pengaruh Kualitas Komite Audit Terhadap Kualitas Laba}

Perusahaan belum berupaya memaksimalkan kinerja kualitas komite audit karena peran komite audit pada peningkatan kualitas laba masih kurang efektif dan minim. Komite audit wajib di seleksi karena bertujuan untuk memberdayakan kegiatan pengendalian dan pemeliharaan dewan komisaris supaya semakin lebih efisien dan efektif. Peran kualitas komite audit belum relevan dalam pengendalian pelaporan keuangan suatu perusahaan dikarenakan kenyataan seringkali masih sebatas formalitas untuk memenuhi persyaratannya dan tidak dapat diartikan sebagai suatu kebutuhan yang sehat dari pengelolaan perusahaan.

Logika pemikiran di atas, sependapat dengan hasil penelitian yang diteliti oleh Aryengki et al (2016), Tulus Suryanto (2016), Bawoni dan Shodiq (2020) yang mengungkapkan bahwa kualitas komite audit memiliki pengaruh positif terhadap kualitas laba.

$\mathrm{H} 2$ : Kualitas komite audit berpengaruh positif terhadap kualitas laba.

\section{Pengaruh Corporate Social Responbility (CSR) Terhadap Kualitas Laba dengan Kualitas Komite Audit Sebagai Pemoderasi}

Dalam penerapan konsep tata kelola perusahaan yang baik, praktik dan pengungkapan CSR merupakan konsekuensi logis yang pada intinya menjelaskan bahwa kepentingan stakeholder perlu diperhatikan oleh perusahaan. Sebagai metode untuk mencapai kualitas kompetitif yang signifikan inisiatif CSR perlu dilihat dari perspektif bisnis. Akibat kegiatan operasional yang dilakukan oleh perusahaan terhadap lingkungan yang menimbulkan masalah sosial, perusahaan harus mempertanggung jawabkan karena praktik CSR dianggap penting bagi perusahaan untuk berorientasi pada keuntungan. Masyarakat akan percaya terhadap produk perusahaan dan reputasi perusahaan menjadi semakin meningkat apabila dilakukan kegiatan CSR, sehingga CSR dapat memberikan dampak positif untuk perusahaan (Widiatmoko, 2020).

Selama dewan komisaris dibantu oleh kualitas komite audit untuk menyakinkan bahwa i) disajikan secara wajar laporan keuangan sesuai pedoman akuntansi yang berstandar umum, ii) struktur pengoperasian dilakukan dengan baik pada internal perusahaan, iii) audit internal dan eksternal dilaksanakan sesuai standar audit yang telah ditetapkan, iv) manajemen melakukan tindak lanjut temuan hasil audit. Oleh sebab itu, kualitas komite audit dapat berperan memoderasi dalam hubungan antara CSR dengan kualitas laba dengan adanya pengetahuan di bidang akuntansi dan keuangan yang dimiliki.

Menurut penelitian yang dilakukan oleh Fauziah dan Marissan (2014) menyimpulkan bahwa kualitas komite audit dapat memoderasi pengaruh CSR terhadap kualitas laba. Karena apabila indeks CSR semakin tinggi maka kualitas laba juga mengalami peningkatan, namun sebaliknya jika indeks CSR rendah maka kualitas laba perusahaan akan semakin menurun. Akan tetapi peneliti sebelumnya menyatakan bahwa peran kualitas komite audit memperlemah hubungan antara CSR terhadap kualitas laba (Witjaksono dan Djaddang, 2018).

H3: Kualitas komite audit memoderasi pengaruh CSR terhadap kualitas laba

\section{Definisi Operasional \\ Kualitas Laba}

Kualitas laba merupakan usaha untuk melindungi kapabilitas perusahaan di awal dan akhir periode agar selalu sama terkait jumlah yang digunakan dalam satu periode. Menurut Bawoni dan Shodiq (2020), Kualitas laba menjadi ukuran untuk menyesuaikan laba yang diperoleh dengan apa yang sebelumnya direncanakan 
apakah sudah sama. Bagi investor laba dapat dipakai acuan untuk memprediksi laba perusahaan di masa mendatang. Oleh karena itu, diperlukannya informasi laba yang relevan, andal dan bebas dari manipulasi (Widiatmoko dan Indarti, 2019).

\section{Corporate Social Responbility (CSR)}

Corporate Social Responbility (CSR) atau tanggung jawab sosial perusahaan merupakan aktivitas operasional perusahaan dalam suatu komitmen perusahaan terhadap masyarakat dan lingkungan. Sebagai pelaku bisnis, perusahaan harus menyadari dan ikut berkontribusi dalam memperhatikan masyarakat serta lingkungan sekitar bahwa perusahaan tidak hanya

menghasilkan laba yang tinggi (Suminar dan Purnama, 2020).

\section{Kualitas Komite Audit}

Kualitas komite audit merupakan efektifitas kemampuan komite di dalam perusahaan. Kualitas komite audit mampu di proksikan menggunakan karakteristik komite audit yang mencakup independensi, kompetensi akuntansi/keuangan, aktivitas serta ukuran komite audit. Keempat indeks tersebut dapat menggantikan komponen-komponen yang dimiliki pada komite audit perusahaan yang berperan untuk menggambarkan kualitas suatu perusahaan (Khafid dan Alifia, 2018).

\section{Pengukuran Variabel}

Tabel 1: Pengukuran Variabel

\begin{tabular}{lll}
\hline \multicolumn{1}{c}{ Variabel } & \multicolumn{1}{c}{ Pengukuran } & \multicolumn{1}{c}{ Sumber } \\
\hline $\begin{array}{l}\text { Kualitas laba } \\
\begin{array}{l}\text { Corporate Social Responbility } \\
\text { CSR })\end{array}\end{array}$ & DAit $=\left(\begin{array}{l}\text { TAit/Ait-1) }- \text { NDAit } \\
\text { CSRDI } j=\frac{\text { Nij }}{\text { Kualitas komite audit }}\end{array}\right.$ & $\begin{array}{l}\text { (Hutasoit, Harahap \& Huda, 2020) } \\
\text { (Kristiawan, 2020) }\end{array}$ \\
& $\begin{array}{l}\text { Kualitas komite audit diukur dengan menjumlahkan } \\
\text { semua nilai yang di dapatkan pada masing-masing } \\
\text { indeks sesuai karakteristik komite audit. }\end{array}$ & (Baxter, 2010) \\
\hline
\end{tabular}

\section{Metode Analisis}

Metode analisis dalam penelitian ini menggunakan Moderated Analysis Regression (MRA), dengan persamaan matematis sebagai berikut:

\section{$K L=\alpha+\beta_{1} \operatorname{CSR} i+\beta_{2} K K A+\beta_{3} K K A$ * CSRi $+e$}

Keterangan:

$\mathrm{KL} \quad=$ Kualitas Laba

$\alpha \quad=$ Konstanta

CSR = Corporate Social Responbility

KKA $=$ Kualitas Komite Audit

$e \quad=$ Standar error

\section{HASIL DAN PEMBAHASAN}

Berdasarkan kriteria pemilihan sampel, terdapat 243 data yang diperoleh. Pengujian normalitas pada tahap pertama membuktikkan hasil bahwa residual tidak terdistribusi normal, maka dari itu perlu dilakukan transformasi sehingga menjadi 204 data. Tabel 2 menyajikan statistik deskriptif untuk semua variabel yang digunakan pada penelitian dalam bentuk nilai minimum, nilai maksimum, nilai rata-rata dan standar deviasi.

Berdasarkan Tabel 2 variabel dependen kualitas laba menunjukkan bahwa nilai minimum sebesar -
36.732.398, dan nilai maximum sebesar 45.105.677, nilai mean dan standar deviasi sebesar 5.493.504,19 dan 13.744.494,826. Nilai rata-rata (mean) yang lebih rendah daripada nilai standar deviasi menunjukkan bahwa data bersifat rendah dan homogen.

Variabel independen Corporate Social Responbility (CSR) menunjukkan bahwa CSR memiliki nilai minimum sebesar 0,143 dan nilai maximum sebesar 0,747 sedangkan nilai mean sebesar 0,56771 dan standar deviasi senilai 0,102367. Maka dengan ini dapat diketahui nilai minimum CSR sebanyak 0,143 pada tahun 2017 adalah perusahaan PT. Indofood Sukses Makmur Tbk (INDF). Nilai maximum CSR sebesar 0,747, yaitu pada perusahaan PT. Berlina Tbk (BRNA) tahun, sedangkan nilai mean CSR pada tahun 2017-2019 sebesar 0,56771 dengan nilai standar deviasi sejumlah 0,102367 .

Variabel kualitas komite audit menunjukkan bahwa nilai minimum kualitas komite audit pada tahun 2017-2019 sebesar 2 diperoleh perusahaan PT Akasha Wira International Tbk (ADES), Tri Banyan Tirta Tbk (ALTO), Tiga Pilar Sejahtera Food Tbk (AISA). Nilai maximum sebesar 4 yaitu pada PT Kimia Farma Tbk (KAEF), Semen Indonesia Tbk (SMGR), Unilever Indonesia Tbk (UNVR). Nilai rata-rata (mean) dan standar deviasi sebesar 3,04 dan 0,447.

KL: Kualitas Laba 
An-Nisha Dewi Puspaningrum dan MG Kentris Indarti, Peran Kualitas Komite Audit dalam Hubungan Corporate Social Responbility dengan Kualitas Laba

Tabel 2: Statistik Deskriptif

\begin{tabular}{llllll}
\hline & N & Minimum & Maximum & Mean & Std. Deviation \\
\hline KL & 204 & -36732398 & 45105677 & 5493504,19 & 13744494,826 \\
CSRi & 204 &, 143 &, 747 &, 56771 &, 102367 \\
KKA & 204 & 2 & 4 & 3,04 &, 447 \\
Valid N & 204 & & & & \\
(Listwise) & & & & & \\
\hline
\end{tabular}

CSRi: Corporate Social Responbility Index

KKA: Kualitas Komite Audit

Tabel 3: Moderated Regression Analysis (MRA)

\begin{tabular}{|c|c|c|c|c|c|c|c|c|}
\hline \multirow[b]{3}{*}{ Model } & \multicolumn{2}{|c|}{ Unstandardized Coefficients } & \multirow[b]{2}{*}{$T$} & \multirow[b]{2}{*}{ Sig. } & \multicolumn{2}{|c|}{ Collinearity Statics } & \multicolumn{2}{|c|}{ Heteroscedasticity Test } \\
\hline & $\mathrm{B}$ & Std. Error & & & Tolerance & VIF & $T$ & Sig. \\
\hline & & & & & & & & \\
\hline (Constant) & $-51902596,371$ & 24082672,282 & 2,155 & ,032 & & & ,839 & ,402 \\
\hline CSRI & 108411684,912 & 38967552,628 & $-2,782$ & ,006 & ,927 & 1,079 &,- 757 & 450 \\
\hline LN_KKA & 30223886,249 & 22150476,857 & $-1,364$ & 174 & ,927 & 1,079 &, 079 & ,937 \\
\hline CSRI_KKA & $-27834348,818$ & 12652304,574 & 2,200 & 029 & & & ,383 &, 702 \\
\hline Zskewness & & & & & & & & 0,858 \\
\hline Zkurtosis & & & & & & & & 1,737 \\
\hline Adjusted $R$ & & & & & & & & $5,9 \%$ \\
\hline Square & & & & & & & & \\
\hline F Statistics: & & & & & & & & 5,524 \\
\hline Sig. & & & & & & & & 0,002 \\
\hline
\end{tabular}

Hasil uji normalitas residual terlihat pada Tabel 3 menunjukkan nilai Zskewness 0,858 , dan nilai Zkurtosis $1,737<1,96$, sehingga residual dalam model regresi normal didistribusikan. Berdasarkan Tabel 3 uji multikolinieritas membuktikkan bahwa semua variabel memiliki varians inflasi faktor (VIF) kurang dari 10, nilai Durbin-Watson adalah 1,954 di antara du 1,7887 dan nilai 4-du 2,2113 dan hasil uji heteroskedastisitas memperlihatkan bahwa seluruh variabel mempunyai nilai signifikansi $>0,05$. Sehingga tidak terjadi masalah pada uji multikolinieritas, autokorelasi, dan heteroskedastisitas di dalam regresi model.

Berdasarkan Tabel 3 Koefisien Determinasi menunjukkan sebuah nilai 0,059 yang berarti 5,9\% dari variasi variabel Corporate Sosial Responbility, kualitas laba, kualitas komite audit, sedangkan sisanya 94,1\% dijelaskan oleh variabel lain di luar model. Nilai $F$ hitung menunjukkan signifikan jumlah 5,524 pada level 0,002 , yang artinya model tersebut layak untuk digunakan. Hasil pengujian hipotesis disajikan pada Tabel 3.

Pada Tabel 3 nilai Koefisien $\beta$ variabel independen Corporate Social Responbility (CSR) menunjukkan nilai sebesar 108411684,912 dan nilai tingkat signifikan $0,006<0,05$. Maka dapat dikatakan bahwa variabel CSR terdapat pengaruh positif dan signifikan terhadap kualitas laba, sehingga hipotesis pertama $\mathrm{H} 1$ diterima.

Logika pemikiran di atas, sepemikiran dengan penelitian yang telah dilakukan oleh Aziz dan Faisol (2018), Hoang et al. (2018), Rezaee et al. (2019) dan Kristiawan (2020), Hidayah et al. (2021) yang menyatakan bahwa Corporate Social Responbility memiliki pengaruh positif terhadap kualitas laba perusahaan. Apabila tingkat manajemen laba tinggi, maka laba yang dilaporkan semakin tidak dapat diandalkan yang berarti Corporate Social Responbility memiliki pengaruh negatif terhadap kualitas laba yang dilaporkan. Apabila CSR yang diungkapkan meningkat maka kualitas laba yang dilaporkan juga semakin tinggi dan sebaliknya.

Penelitian ini bertentangan dengan hasil penelitian yang dilakukan Siueia dan Wang (2019) yang membuktikkan bahwa Corporate Social Responbility memiliki pengaruh signifikan ke arah negatif terhadap kualitas laba. Hal ini dikarenakan bahwa manajer menggunakan aktivitas CSR dan laporan sebagai insentif oportunistik untuk menutupi kesalahan perusahaan.

Variabel kualitas komite audit menunjukkan bahwa nilai Koefisien $\beta$ sebesar 30223886,249 dan nilai signifikansi sebesar $0,174>0,05$ yang berarti dapat disimpulkan bahwa variabel kualitas komite audit tidak berpengaruh positif signifikan terhadap kualitas laba, sehingga hipotesis $\mathrm{H} 2$ ditolak. Rendahnya praktik penerapan corporate governance di dalam suatu perusahaan menyebabkan tidak adanya pengaruh yang signifikan antara hubungan kualitas komite audit dengan kualitas laba. Karena Perusahaan belum mampu mengoptimalkan kinerja kualitas komite audit. Hasil penelitian ini tidak sejalan dengan penelitian yang dilakukan Bawoni dan Shodiq (2020) yang menunjukkan bahwa kualitas komite audit berpengaruh positif terhadap kualitas laba sedangkan penelitian lain yang dilakukan oleh Sayuthi (2017) yang menyatakan bahwa komite audit berpengaruh negatif terhadap kualitas laba. Penelitian ini konsisten dan didukung dengan penelitian sebelumnya yang dilakukan oleh Puspitowati dan Mulya (2014) yang menemukan bahwa kualitas komite audit 
tidak berpengaruh secara signifikan terhadap kualitas laba. Sehingga, hasil penelitian ini dikuatkan oleh penelitian sebelumnya yang membuktikkan bahwa kualitas komite audit tidak memiliki pengaruh yang signifikan terhadap kualitas laba.

Hasil pengujian hipotesis variabel moderasi (CSRi*KKA) menujukkan bahwa nilai koefisien $\beta$ sebesar -27834348,818 dan nilai signifikan sebesar 0,029>0,05 yang berarti variabel Corporate Social Responbility terdapat pengaruh terhadap kualitas laba ketika dimoderasi oleh kualitas komite audit, sehingga hipotesis H3 ditolak. Corporate Social Responbility masih dianggap oleh pasar masih hanya sebagai management impression untuk perusahaan, karena akan memberikan sinyal positif bagi investor apabila perusahaan telah membentuk reputasi dan citra perusahaan untuk menciptakan suatu nilai (value creation). Menurut komite audit, dalam melaksanakan CSR hanya sebagai keuntungan laba positif saja. Jika perusahaan mengalami keuntungan atau laba positif, maka CSR dapat dijalankan dengan baik. Demikian sebaliknya jika perusahaan mengalami kerugian atau laba negatif, maka CSR masih belum berperan memberikan kontribusi atas kebutuhan lingkungan perusahaan. Penelitian ini sejalan dengan penelitian yang dilakukan oleh Fauziah dan Marissan (2014) yang menemukan bahwa indeks CSR berpengaruh signifikan terhadap kualitas laba perusahaan. Karena apabila indeks CSR tinggi maka kualitas laba perusahaan akan semakin meningkat dan sebaliknya.

\section{SIMPULAN}

Berdasarkan hasil dan pembahasan diatas tentang pengujian pengaruh Corporate Social Responbility terhadap kualitas laba dengan kualitas komite audit sebagai variabel moderasi dapat disimpulkan sebagai berikut:

1. Corporate Social Responbility berpengaruh positif signifikan terhadap kualitas laba.

2. Kualitas komite audit tidak berpengaruh signifikan terhadap kualitas laba.

3. Kualitas komite audit memperlemah pengaruh Corporate Social Responbility terhadap kualitas laba.

Apabila Corporate Social Responbility yang dimiliki perusahaan semakin maka kondisi kualitas laba suatu perusahaan juga akan semakin meningkat. Kualitas komite audit belum berpengaruh secara optimal terhadap peningkatan kualitas laba karena masih belum berperan penting, karena kualitas komite audit masih sebatas berperan sebagai pemenuhan syarat dari Otoritas Jasa Keuangan (OJK) di dalam suatu perusahaan yang telah terdaftar di Bursa Efek Indonesia (BEI), namun demikian peran kualitas komite audit akan semakin diperlukan di masa mendatang untuk melaksanakan CSR sebagai mandatory disclosure (Witjaksono dan Djaddang, 2018).
Terlepas dari kontribusi yang bisa diberikan, penelitian ini memiliki beberapa keterbatasan yang memerlukan penyempurnaan dan pengembangan pada penelitian selanjutnya. Keterbatasan tersebut antara lain yaitu nilai Koefisien Determinasi $\left(\mathrm{R}^{2}\right)$ yang relatif rendah hanya sebesar $0,059 \quad(5,9 \%)$. Berdasarkan keterbatasan penelitian tersebut, maka peneliti memberikan saran sebagai berikut: penelitian selanjutnya sebaiknya memasukkan variabel-variabel kontrol seperti return on asset, leverage, size dan memperpanjang periode amatan, sehingga dapat lebih menjelaskan pengaruhnya terhadap kualitas laba.

\section{DAFTAR PUSTAKA}

Aryengki, R., Satriawan, R. A., \& Rofika. (2016). Pengaruh Komite Audit, Kualitas Audit, Likuiditas Dan Ukuran Perusahaan Terhadap Kualitas Laba. JOM Fekon, 3 (1), 2192-2206.

Aziz, A. J., \& Faisol, D. A. (2018). Pengaruh Corporate Social Responbility Terhadap Kualitas Laba. Jurnal Akunida , 3 (1), 1-20.

Baxter, Peter. 2010. "Factors associated with the quality of audit committees". Pacific Accounting Review, Vol. 22 No. 1, pp. 57-74.

Bawoni, T., \& Shodiq, M. J. (2020). Pengaruh Likuiditas, Alokasi Pajak Antar Periode Dan Komite Audit Terhadap Kualitas Laba. Prosiding Konferensi Ilmiah Mahasiswa Unissula (KIMU) Klaster Ekonomi. , 790-809.

Fauziah, F. E., \& Marissan, I. (2014). Pengaruh Corporate Social Responsibility (CSR) Terhadap Kualitas Laba Dengan Corporate Governance Sebagai Variabel Moderating. Jurnal Akuntansi \& Auditing , 11 (1), 39-61.

Hidayah, R., Sholih, A., Agustina, L., \& Rahayu, R. (2021). The Determinant of Earnings Quality Using State Ownership as Moderating Variable on Companies in Malaysia. Jurnal Economia , 17 (1), 34-48.

Hoang, T. C., Abeysekera, I., \& Ma, S. (2018). Earnings Quality and Corporate Social Disclosure: The Moderating Role of State and Foreign Ownership in Vietnamese Listed Firms. Emerging Markets Finance and Trade , 1-17.

Hutasoit, S., Harahap, K., \& Huda, A. (2020). Pengaruh Corporate Social Responsibility Terhadap Earning Quality. Jurnal Akuntansi, Keuangan \& Perpajakan Indonesia , 8 (1), 1-10.

Khafid, M., \& Alifia, D. (2018). Peran Moderasi Kualitas Komite Audit terhadap Pengaruh Struktur Kepemilikan atas Pengungkapan Modal Intelektual. Jurnal Dinamika Akuntansi , 10 (1), 27-39.

Kristiawan, N. B. (2020). Corporate Social Responsibility, Concentrated Ownership Structures, And Earnings Quality In Indonesian 
Companies. Jurnal Ilmiah Akuntansi , 4 (3), 310321.

Lestari, P. P., \& Feliana, Y. K. (2019). Hubungan Corporate Social Responsibility dengan Earnings Quality. Jurnal Akuntansi dan Teknologi Informasi , 13 (2), 1-26.

Puspitowati, N. I., \& Mulya, A. A. (2014). Pengaruh Ukuran Komite Audit, Ukuran Dewan Komisaris, Kepemilikan Manajerial, Dan Kepemilikan Institusional Terhadap Kualitas Laba. Jurnal Akuntansi dan Keuangan , 3 (1), 219-239.

Rahmawardani, D. D., \& Muslichah. (2020). Corporate Social Responsibility Terhadap Manajemen Laba Dan Kinerja Perusahaan. Jurnal Riset Akuntansi Kontemporer, 12 (2), 52-59.

Rezaee, Z., Dou, H., \& Zhang, H. (2019). Corporate Social Responbility and Earnings Quality: Evidence from China. Global Finance Journal , 121.

Sayuthi. (2017). Pengaruh Audit Tenure dan Komite Audit Terhadap Kualitas Laba. Jurnal Ekonomi Islam, 13 (2), 127-145.

Siueia, T. T., \& Wang, J. (2019). The Association Between Corporate Social Responbility and Earnings Quality: Evidence from Extractive Industry. Revista De Contabilidad Spanish Accounting Review , 22 (1), 112-121.

Suminar, R., \& Purnama, D. (2020). Analisis FaktorFaktor Yang Mempengaruhi Pengungkapan Tanggung Jawab Sosial Perusahaan. Jurnal Ekonomi Akuntansi Dan Manajemen , 1 (1), 5063.

Suryanto, T. (2016). Pengaruh Accounting Disclosure, Accounting Hamonization dan Komite Audit. Jurnal Akuntansi , 20 (2), 190-201.

Widiatmoko, J. (2020). Corporate Governance Mechanism and Corporate Social Responsibility on Firm Value. Relevance: Journal of Management and Business, 3 (1), 13-25. DOI: https://doi.org/10.22515/relevance.v3i1.2345

Widiatmoko, J., \& Indarti, M. K. (2019). Book Tax Differences, Operating Cash Flow, Leverage and Earnigs Persistence in Indonesia Manufacturing Companies. Jurnal Dinamika Akuntansi , 11 (2), 151-159.

Witjaksono, R. B., \& Djaddang, S. (2018). Valuasi Kesadaran Lingkungan, Corporate Social Responsibility Terhadap Kualitas Laba dengan Moderasi Komite Audit. Jurnal Ekonomi dan Bisnis , 21 (1), 97-114. 